\title{
The US ban on Turkmen Cotton and It's Impact on Turkmenistan's Trade Relationship with Turkey
}

\author{
Emre Eren Korkmaz ${ }^{1}$ 우
}

\begin{abstract}
As a consequence of many independent reports arguing that forced labour is being widely used to pick cotton in Turkmenistan, the U.S. Customs and Border Protection announced a ban on the import of cotton from Turkmenistan on May 18 2018. As a significant textile producer, Turkey is one of the primary global trading partners of Turkmenistan which includes the products made of cotton, and these products may be exported to the U.S. and other Western markets. Turkish foreign investment in the Turkmen garment industry is worth analysing because these textile factories produce mainly for the international market, not for domestic consumption. As Turkish investment in the sector is for export, the outputs are expected to be sold in the global market within the supply chains of global brands. Therefore, the various international campaigns against the country that resulted in corporate decisions to stop sourcing Turkmen cotton-have dealt a blow to the economic relationship of both countries. This article aims to map the trade relations between two countries and summarizing the approaches of social actors in the garment industry based on a literature review and interviews with industry social actors.
\end{abstract}

\section{Keywords}

Turkmen cotton, Forced labour, Modern slavery, Turkish garment supply chain, Global corporations, Corporate social responsibility, Multi-stakeholder initiatives

\section{ABD’nin Türkmen Pamuğu Yasağı ve Bunun Türkmenistan'ın Türkiye ile Ticaretine Etkisi}

Öz

Türkmenistan'da pamuk hasadında yaygın şekilde zorunlu işgücünün kullanıldığına dair çok sayıda bağımsız raporun sonucunda ABD yönetimi Türkmenistan'dan pamuk ithalatın 18 Mayıs 2018 tarihinde yasakladı. Önemli bir tekstil ülkesi olan Türkiye ise Türkmenistan'ın pamuk ve pamuklu tekstil ürünü ithalatında en önemli ticari ortağı durumunda ve bu ürünlerin $A B D$ ve Bat piyasalarına Türkiye üzerinden dağıtımaya devam etmesi de bir ihtimal. Türkmen tekstiline yönelik Türk dış yatırımı bu açıdan analiz edilmeye değer, çünkü bu fabrikalar iç pazar için değil uluslararası piyasalar için üretimlerini sürdürüyorlar. Türk şirketleri sözkonusu yatırımları küresel piyasaları dikkate alarak yaptı̆ı için birçok küresel giyim markasının uluslararası kampanyalar sonucunda tedarik zincirinde Türkmen pamuğu kullanımını yasaklaması iki ülke arasındaki ticari ilişkilere önemli bir etkide bulunmuştur. Makalede literatür taramasına ve mülakatlara dayanarak her iki ülke arasındaki ticari ilişki analiz edilecek ve tekstil endüstrisindeki sosyal tarafların Türkmen pamuğuna yönelik yasağa karşı tutumları değerlendirilecektir.

\section{Anahtar Kelimeler}

Türkmen pamuğu, Zorunlu emek, Modern kölelik, Türk tekstil tedarik zinciri, küresel şirketler, Kurumsal sosyal sorumluluk, Çok paydaşlı inisiyatifler

1 Correspondence to: Emre Eren Korkmaz (Dr.), University of Oxford, Department of International Development, Oxford, United Kingdom. E-mail: emre.korkmaz@qeh.ox.ac.uk ORCID: 0000-0003-3124-7893

To cite this article: Korkmaz, E. E. (2019). The US ban on Turkmen cotton and it's impact on Turkmenistan's trade relationship with Turkey. SiYASAL: Journal of Political Sciences, 28(2), 237-255. http://doi.org/10.26650/siyasal.2019.28.2.0033 


\section{The US ban on Turkmen Cotton and It's Impact on Turkmenistan's Trade Relationship with Turkey}

Many independent reports argue that forced labour is being widely used to pick cotton in Turkmenistan. While global brands, the trade union movement and various NGOs have focused on the sweatshop conditions in the garment supply chain in various countries, forced labour organized by governments has not attracted nearly as much attention (Amnesty, 2018; Ergon, 2018; European Commission, 2018; Skrivankova, 2018; Skrivankova, 2015).

Land in Turkmenistan, is almost all state-owned and is leased to farmers on whom a cotton production quota is imposed by the state. Considered "white gold" for the authorities, the revenue gained from raw cotton is an essential contributor to the central state budget. For this reason, every year, tens of thousands of civil servants, studentsand even children - are reportedly dispatched to rural areas by government officials to pick cotton in hot, hazardous and unsanitary conditions (Skrivankova, 2018; Pomfret, 2016; Turan and Dinç, 2015).

U.S. Customs and Border Protection announced a ban on the import of cotton from Turkmenistan on May 182018 and this attracted attention to Turkey's trade and economic relations with Turkmenistan. As a significant textile producer, Turkey is one of the primary global trading partners of Turkmenistan which includes the products made of cotton, and these products may be exported to the U.S. and other Western markets. This article aims to map the trade relations between two countries, summarizing the approaches of social actors in the garment industry, and underline the principal risks following the US ban on Turkmen cotton.

This paper aims to investigate whether the ban on Turkmen cotton could be broken via Turkish investors in Turkmenistan. The US and many global garment brands ensure that they will not purchase Turkmen cotton until Turkmen authorities take transparent steps towards the abolition of modern slavery in cotton production. However, Turkmenistan refuses to take any positive step towards the resolution of this question and insists on the same system in cotton production. As the principal investor and trade partner of Turkmenistan is Turkey, various questions arise from the special political relations between both countries. Such a tight political and economic relationship between the two countries is the source of concerns about the effectiveness of the ban and if Turkmen cotton is distributed to the world market via Turkey.

The limitations of this investigation will be explained in the Methodology section. However, despite the ban declared by various global brands, they do not have any effective auditing systems for the origins of cotton in the Turkish supply chain. Additionally, there is a risk of exporting garments from Turkmenistan to Turkey and labeling them as Turkish products. This paper examines the potential risks on the use of Turkmen cotton.

\section{Methodology}

This article is written by acquiring data from various sources including a fieldwork trip to Istanbul in October 2016. The literature review, media review and interviews were the primary methods to map the trade relationship between the two countries. 
The literature review is based on the academic papers, unpublished master and doctorate dissertations, policy briefings of various international associations and thinktank organisations and country reports of local, central and international business associations.

The media review was conducted through searching mainstream international and Turkish national media and this review was complemented by analysing reports of industry-oriented journals and a pro-Turkmen government Turkish news site (TürkiyeTürkmenistan). The information gained from these sources are tested and verified through the Alternative Turkmenistan News which is the leading independent media organ.

The interviews were conducted through various methods:

* Two Turkish trade unions (Deriteks and DISK Tekstil) and three Turkish suppliers were interviewed in Istanbul in the first week of October 2018.

* Four managers working at Turkish textile plants in Turkmenistan answered questions via phone in the first week of November 2018. We anonymised the names of these managers.

* All other representatives of organisations answered written questions. Answers were collected throughout October and November 2018. These comprise:

- three business associations in the garment-textile industry (ITKIB, TTSIS and TGSD),

- two multi-stakeholder initiatives (ETI, FWF)

- the local office of Better Cotton

- academics dealing with Central Asia and Turkmenistan in the UK, Turkey and Russia

- Four global brands sourcing from Turkey (H\&M, Inditex, Primark, El Corte Ingles). M\&S, Next and Puma accepted to answer our questions, but they did not send their answers until the article was written up.

- The commercial consular of the Turkish Embassy in Ashgabat, Turkmenistan did not want to comment on questions which is considered as a meaningful response for the research.

Therefore, in addition to the literature and media review, the fieldwork covered all social actors of the industry that may have an interest in the trade links relating to cotton production between Turkey and Turkmenistan.

However, it is a requirement to explain the challenges of the research.

First of all, Turkmenistan is a closed and isolated country. The country is only a member of the UN and the IMF in terms of international organisations. There is no independent media, academia or civil society. There aren't any alternative, independent or neutral sources for gathering and analysing data. The state does not publish statistics accurately, and the existingstatistics are collected from statements of the President and other political figures. The data on the country (from revenue gained from the amount of harvested cotton) is not collected based on scientific and universal methods. Different international sources estimate contradictory figures, and it is possible to find out different data from Turkmen, Turkish or the US sources (Peyrouse, 2015; Payzyllayev, 2007; Ponfret, 2011; Stronski, 2017; Mogilevski, 2012). Therefore, the data shared in this report is the most accurate data which is checked and confirmed by Turkish exporters. The article will not share many figures and tables of statistics because of this reason and will aim to share findings of the research based on qualitative methods. 
There were also challenges for literature review. The article examined academic papers, articles, dissertations and books on Turkmenistan. However, there isn't much interest in Turkmenistan in academia. Many papers be found on Central Asia, but very few of them focus on the country. Many academic papers and dissertations on Turkmenistan in Turkish are lacking in the standard academic principles that should be considered carefully before referencing them. The majority of academic papers meeting the minimum international academic standards is focusing on the environmental and geographical aspects of cotton protection. Economic analysis of cotton production and trade is rare, and many of them rely on inaccurate Turkmen data. Many country reports of local and national business associations in Turkey also repeat the same arguments providing examples of plagiarism, and they are lacking serious study (Kovusava, 2018; Merrill, 2015). The reliable sources produced by international NGOs, think tanks and universities generally focus on the foreign policy and gas/oil exportation of the country and not much information is shared on cotton and textile. Therefore, this article analysed all the literature shared in the bibliography and struggled to overcome these challenges to illustrate more accurate, verifiable and testable pieces of information.

The last challenge was experienced during interviews with industry stakeholders. It was not only the Turkish Embassy in Turkmenistan but also almost all industry stakeholders who were reluctant to answer our questions on Turkmen cotton in Turkey. Even many global brands which had openly declared not to source Turkmen cotton preferred not to share detailed answers in contrast with other agendas on Turkey-related issues. For instance, both Corporate Social Responsibility departments of brands and Turkish business associations share detailed information on their projects about the legal employment of Syrian refugees in Turkey or social dialogue between trade unions and employers with many best-practices, whereas there has not been a similar approach towards Turkmen cotton. In anthropology, "nothing also means something". Here, answers of industry stakeholders will be shared, and this reluctance will be examined in the second half of the article. As almost all interviewees requested from us to anonymise the information they shared with the research, in the section discussing the approaches of industry stakeholders, the article will mainly share common points of each stakeholder.

\section{Turkmen Cotton and Turkey}

Turkmenistan, with a population of 5.4 million, has a strong presidential system characterized by isolated, authoritarian, one-person rule and is one of the most repressive regimes of the world (Bohr, 2016). Although Turkmenistan officially bans the use of forced or compulsory labour based on its international commitments, it is a closed country and its authoritarian regime does not allow any independent local or international authority to audit labour market practices. Moreover, officially there is no unemployment in the country. Nevertheless, independent research asserts a real unemployment rate of around $60 \%$, with over $30 \%$ of the population living under the poverty line. This is despite Turkmenistan's abundant natural resources and a literacy rate that is amongst the highest in the world (Amnesty, 2018; Güneş, 2014; Peyrouse, 2015; Pomfret, 2014; Terzioğlu, 2013).

While $80 \%$ of Turkmenistan's exports are natural gas and $10 \%$ are in petroleum goods, cotton and textile products make up $8 \%$ of total exports. Turkmenistan is in the top ten 
cotton producers in the world. In 2016, the leading destination countries for Turkmenistan's exports were China (US\$8.59B), Turkey (US\$612M), Italy (US\$493M), the United Kingdom (US\$195M) and Germany (US\$172M). The top countries for Turkmenistan's imports were Turkey (US\$2.19B), Russia (US\$1.14B), China (US\$921M), Ukraine (US\$431M) and Kazakhstan (US\$353M) (Bashimov, 2016; Bashimov and Çiçek, 2016; Jumayev, 2012; Kandiyoki, 2005; Pastor and Rooden, 2000).

Textiles is one of the few industries providing much-needed foreign currency for Turkmenistan. Alongside Turkey's appetite for the vast bulk of Turkmen cotton exports, Turkish firms have been leading foreign investors in the development of the local textile industry. These Turkish investors have been at the forefront of modernization of the industry, opening state-of-the-art textile facilities and creating thousands of new jobs (Konca, 2011; Samsun TSO, 2016; Sirtığlu, 2018; MUSIAD, 1996; ORASAM, 2018, Bashimov and Çiçek, 2015).

The state preserves a monopoly on the marketing of all cotton. Like the other Central Asian states, in Turkmenistan the purpose of agricultural policies is to create and distribute rents for the ruling elite, and all incentives for policymakers reflect the fragility of the regime, not the interests of classical political majorities or interest groups (Petrick, 2016). As mentioned by a Chatham House report, since the collapse of the Soviet Union in 1991, the country has experienced a near-total absence of liberalization, in either form or substance (Bohr, 2016).

The accuracy of official data on Turkmen cotton is highly dubious. While Turkmen authorities claimed that over 1 million tonnes of raw cotton was produced in 2017 (TRT Avaz, 2018), international organizations, academic research and Turkish exporters estimate the amount was around 300,000 tonnes (Bashimov, 2016), with the country ranking $7^{\text {th }}$ in the league of world cotton production. The official 2018 production target is also set at 1 million tons of raw cotton (Orasam, 2018). Official documents and President Gurbanguli Berdimuhammedov's speeches repeatedly underline the strategic significance of cotton production. For instance, the 2012-2016 Turkmenistan Textile Industry Program had anticipated over US\$1 billion in foreign investment in the textile industry and further attempts at fully mechanizing production.

Even controversial official figures demonstrate the significance of the textile industry and cotton production. For instance, in the first four months of 2013, annual growth in the Turkmen textile industry was reported to have been $105 \%$, with a $102.6 \%$ increase in sales and a $13.4 \%$ rise in profit margins. (Türkiye-Türkmenistan, 2014)

\section{Turkey's "Special” Political Relationship with Turkmenistan}

The so-called "special political relationship" between Turkey and Turkmenistan has been underlined repeatedly since 1991. The historical, cultural and linguistic affinity between the two are given as the source of the special relationship. Like Turkey-Azerbaijan relations, the axiom most commonly associated with the political relationship between Turkey and Turkmenistan is "one nation-two states". For instance, in March 2015 then Turkish Minister of Economy, Nihat Zeybekci, stated at the Turkmenistan Investment Forum that he also considered himself to be a Turkmen public servant, thus actively taking account of the economic interests of Turkmenistan as well (Güneş, 2014; DEIK, 2015). 
The special relationship also motivates private companies, investors and entrepreneurs to establish business links between these countries. Additionally, the close political relationship paves the way for Turkish companies to establish joint ventures with Turkmen state companies and win projects and tenders that allows them to skip the nontariff barriers that face other foreign bidders (TİKA, 2004). An example of this is Turkey's Ziraat Bank is one of the very few foreign banks operating in Turkmenistan (Ateş, 2012; Konca, 2011; Samsun TSO, 2016; S1rtıŏlu, 2018).

On a political level, Turkey could be considered the fifth most influential player in Turkmenistan, following Russia, China, the U.S., and the EU. Turkey was the first country to recognize the independence of Turkmenistan after the collapse of the Soviet Union in 1991. In the early 1990s, linguistic, historical and cultural affinities saw Turkey pursue a more affective, nationalist, pan-Turkic approach toward Central Asia, supported by Western powers. However, Turkey soon realized the heavy legacy of the Soviet period and its limits as a regional power, which tempered ambitions and cautioned a more gradualist approach. After 1995, therefore, Turkey followed a more pragmatic approach toward the region that focused on developing soft power and consolidating tangible links (Güneş, 2014).

As part of this pragmatic approach, Turkey became - for the first time in its history-a donor country, providing developmental aid to Central Asian countries through Ankara's overseas developmental bureau, the Turkish Cooperation and Coordination Agency (TIKKA). Official development aid to Turkmenistan has totaled over US\$166 million since 2004. Apart from official relationships, many corporations, public agencies, schools, NGOs and religious foundations have operated in Central Asian countries including Turkmenistan, conducting a range of commercial and cultural projects (Güneş, 2012).

While the big players of world politics competed in the region to control gas and oil reserves, Turkish businesses adopted a niche strategy, focusing on industries and sectors such as textiles, construction, and food services - even establishing monopoly positions in some. All this came as Turkish business continued to look for new external markets after local export-led industrial capital formation occurred during the neo-liberal economic transformation in Turkey in the 1980s. The independence of Central Asian countries after the Cold War was seen as excellent opportunity for Turkish companies — as early as 1992, over 200 Turkish companies had invested in the region (Güneş, 2012).

\section{Turkey's Economic and Trade Relationship with Turkmenistan}

According to Turkey's Ministry of Foreign Affairs, ${ }^{1}$ there are 600 Turkish companies operating in Turkmenistan. Turkey is the country's fourth largest trading partner after China, Russia and Iran. The main import categories for Turkey are gas, oil, cotton, gold and garments while Turkey exports steel and construction materials to Turkmenistan. According to official U.S. sources, ${ }^{2}$ in 2017 Turkey was Turkmenistan's second most significant export partner $(5.1 \%$ of exports - China was the first with $83.7 \%)$ and the most significant import partner (24.2\% of imports).

1 http://www.mfa.gov.tr/turkmenistan-ekonomisi.tr.mfa

2 https://www.cia.gov/library/publications/the-world-factbook/geos/tx.html 
Table 1

Turkey's trade relations with Turkmenistan (Source: Ministry of Foreign Affairs, Republic of Turkey)

\begin{tabular}{|l|l|l|}
\hline Year & Imports & Exports \\
\hline 2010 & US\$386.3 million & US\$1,139.1 million \\
\hline 2011 & US\$392.7 million & US\$1,493.3 million \\
\hline 2013 & US\$653.6 million & US\$1,957.5 million \\
\hline 2014 & US\$624.1 Million & US\$2,232.8 million \\
\hline 2015 & US\$557.4 million & US\$1,859.3 million \\
\hline
\end{tabular}

Turkey has adopted a long-term approach to its economic and trade relationship with Turkmenistan. For instance, the Lapis Lazuli Transit Motorway project is constructing an international roadway that will pass through Afghanistan to Turkmenistan, Azerbaijan, Georgia and Turkey towards Europe. This is a part of the Greater Silk Road Project. Turkish construction companies have been commissioned to lead around 1,400 projects in Turkmenistan, with a value of US\$48 billion, which is approximately $70 \%$ of the total. Energy, textile and infrastructure companies have followed construction companies. Additionally, $60 \%$ of Turkmenistan's local Coca-Cola bottler is owned by Turkey's Anadolu Group.

\section{Recent Data on Turkmen Cotton in Turkey}

According to the statistics of the Turkish Textile-Garment Exporters Association:

* Turkey's raw cotton imports from Turkmenistan between January and August 2018 totaled US\$73.7 million, a $37.3 \%$ fall from the previous year.

* In the same eight-month period, Turkey's total raw cotton imports amounted to US\$1.2 billion-meaning the Turkmen share of cotton imports was $6.3 \%$. This was down from an $8 \%$ share in 2017.

* Additionally, cotton imports from Turkmenistan to Turkey fell $21.8 \%$ in 2016-17. As recently as 2013, Turkey's imports of raw cotton, cotton yarn and cotton knitted fabric from Turkmenistan had been US\$436 million.

The U.S. ban on Turkmen cotton is the key reason for this decline. The other reason is the increase in local Turkish production, which saw a decline in imported cotton of $9.5 \%$ in 2018 .

* In the same period (January-August 2018), textile imports from Turkmenistan to Turkey were valued at US $\$ 176.5$ million or $2.8 \%$ of the total textile imports by value.

* Garment imports from Turkmenistan amounted to just US\$225 million or $0.02 \%$ of total garment imports.

Although Turkey's consumption of Turkmen cotton forms a small percentage of the total overall - and it is not a big challenge for Turkey to find alternative markets - for Turkmenistan, the reverse does not hold. Turkey is an important market for the country's raw cotton. In 2014, for example, $83.5 \%$ of all Turkmen raw cotton exports went to Turkey, with an overall value of US\$453 million. 


\section{Turkish Foreign Investment in the Turkmen Textile Industry}

The amount of foreign direct investment to the country's textile industry has exceeded US $\$ 1.5$ billion since independence. The Turkmen textile industry is $22 \%$ foreign owned, and Turkish firms make up $90 \%$ of foreign direct investors. ${ }^{3}$ Çalık Holding, Norsel, Cotam, Polimeks, Nebo, Linkway and Engin Group are among these companies investing in the Turkmen textile industry, opening factories in various regions where cotton is produced.

Cotton-dependent countries aim to establish textile and garment industries as a developmental strategy to liberate themselves from long-term variability in prices and the competition from synthetic products - as well as to access opportunities to export value-added products to the world market (Baffles, 2005). However, the investment environment has been underdeveloped in Turkmenistan. This is one of the reasons that Turkish companies generally invest directly through joint ventures, forming partnerships with public companies or organizations. A TIKKA report (2004) highlighted the three main challenges Turkish investors face in Turkmenistan. Although the report was written 14 years ago, based on our interviews with social actors its findings remain relevant.

The first challenge is the long delays in payment that Turkish companies face due to Turkmenistan's deteriorating balance of payments situation as a result of the fall in oil and gas prices. Some companies have had to accept payment in raw cotton, and when cotton production has fallen below projections, these companies have not had payments on time.

The second challenge is the lack of financial support. Companies face difficulties in obtaining foreign loans, and even where finance is forthcoming, Turkmen authorities might ask for additional guarantees that risk the loan.

The third challenge is that it is possible to find a gap between the official data shared by both countries as a result of double billing or re-pricing of some products on the raw materials market. The preparation and publication of Turkmen statistics is also not consistent with international standards.

A Chatham House report describes the foreign investment environment as follows which can be added to the above challenges:

"Corruption and the general lack of transparency in the regulatory system have created a difficult climate for foreign investment, and decisions to allow it are still politically driven and negotiated on a case-by-case basis with the highest leadership echelons. Foreign companies remain vulnerable to political interference and the arbitrary expropriation of assets. (...) The World Bank does not even include Turkmenistan in its annual Doing Business report. The 2015 Index of Economic Freedom classed the country as 'repressed', ranking its economy as the 172nd-freest out of a total of 178, just above Equatorial Guinea and Eritrea. Turkmenistan ranked last in the world for its investment regime. (...) The awarding of contracts to construct large infrastructure assets, such as ministry buildings, hotels or airports, is a preferred means of providing elites with opportunities to pocket funds because reporting of capital expenditure is opaque. Foreign contractors regularly pay kickbacks to officials. The inflated budgets for such projects, coupled with a lack of accountability, allow high-ranking officials to siphon off funds, enabling the top leadership to distribute significant resources to its inner circle. (...) The best way to penetrate the market is through highranking foreign officials or established foreign businessmen who arrange deals through their personal relationships with top leaders in Turkmenistan. There are various ways for the

3 http://www.turkiye-turkmenistan.com/turkmenistanda-tekstilde-yeni-donem/. 
government to discriminate against foreign investors who have fallen out of favour with the leadership, such as excessive tax examinations, denials of licence extension, non-payment of debts, non-delivery of goods and services, and renegotiation of contracts." (Bohr, 2016)

Turkish foreign investment in the Turkmen garment industry is worth analysing because these textile factories produce mainly for the international market, not for domestic consumption. For this reason, apart from raw cotton, textile production has not garnered much attention. As a consequence of Turkish investments, Turkmenistan has been able to export textile products rather than just raw cotton. From 2001 to 2013, the value of textile and garment exports increased three-fold, reaching US\$640 million. The share of cotton fiber exports decreased from $19.7 \%$ in 1996 to $4.6 \%$ in 2010 as a result of the domestic industrial production of finished goods. Today, almost half of Turkmenistan's raw cotton can be processed within the country, and the majority of that production is exported (Bashimov, 2015; Jumayev, 2012).

\section{Company Case Studies}

In this section, some of the prominent companies investing in Turkmenistan and trading raw cotton from the country will be elaborated based on the media reports mentioned at the References. Despite the low level of transparency of these corporations, a media review disclose significant information to understand the business model and their relationship with the ruling elite.

* The head of Norsel International, Ibrahim Koluk has a long relationship with Turkmenistan, having been doing business there since 1992. The company's first textile industry investment was in 2003, and Mr Koluk was honoured with a medal from the Turkmen government for his role in boosting local industry. ${ }^{4}$

Norsel's facilities are state-of-the-art and the Turkmenabat Cotton Spinning Factory is the largest plant in the Commonwealth of Independent States. These facilities have all been opened to great fanfare, with current President Berdimuhamedov — and before him founding President Niyazov—headlining the ceremonies.

* In 2013 President Berdimuhamedov authorized Engin Group 5 to construct three cotton processing plants - in Ahal, Mary and Dasoguz, respectively - and the owner of the company was also awarded a medal of honour by the government. In 2009, the firm opened a spinning mill factory in Turkmenab that employs 500 people.

* Another important company is Polimeks. Its proprietor, Erol Tabanca, has been investing in construction and textiles in Turkmenistan since 1992, and as a result of these investments - which include the main airport and many monuments and facilities - his company has grown to become the $56^{\text {th }}$ largest construction company on earth. He is on Forbes' list of billionaires.

Mr Tabanca was also appointed as a deputy minister in Turkmenistan's Ministry of Public Works and an assistant to the city planner of Ashgabat city.

However, Mr Tabanca attracted unwanted media attention in March 2018 with claims he had been held captive by Turkmen authorities for a period, after the parties could

4 http://www.hurriyet.com.tr/ekonomi/tekstilde-turmenistana-1-milyar-dolar-yatirdik-178632

5 http://www.turkiye-turkmenistan.com/turk-firmasina-onemli-gorev-3/ 
not agree on the terms for financing of a grand motorway project in the country. ${ }^{6}$ The company denied these allegations. However, the claims cast a bright light on the business environment in Turkmenistan. There have been many legal cases initiated by Turkish companies (mainly in the construction industry) against Turkmenistan seeking damages for financial undertakings not fulfilled on time.

* Çalık Holding is the leading distributor of Turkmen cotton in Turkey. In 2014, Ahmet Çalı, ${ }^{7}$ the head of Çalık Holding, told a press conference that the group's Turkmen textile plants were employing 7,500 workers and reported investments in a number of different sectors covering over 100 projects.

Turkmenistan's then President Niyazov appointed Çalık as a deputy minister within the Ministry of Textiles.

The Chatham House report on Turkmenistan provides striking information about the governing style of the Turkmen authorities, also offering details about Çalık Holding's role in that context:

"Of special note is the Turkish businessman Ahmet Çalik, who not only acted as the primary intermediary between Turkey and Turkmenistan under Nyýazow, but was one of his closest advisers and a seemingly permanent fixture at cabinet meetings and sessions of the national People's Council. For a time Çalik even headed the State Agency for the Management and Use of Hydrocarbon Resources. Shortly after taking power as president, Berdimuhamedow temporarily sidelined Çalik, even refusing him a visa at one point. By some accounts, this fall from grace was due to Berdimuhamedow's unmet demands for information held by Çalik regarding certain off-budget funds that had been deposited offshore by Nyýazow. In any event, by 2009 Çalik had regained favour with the Turkmen leadership. Today the Çalik Holding group of companies is currently undertaking a number of major projects in the country, including the construction of the new international port in Türkmenbasy and a fiveyear plan to improve Asgabat's power supply. (Bohr, 2016)"

\section{The Approaches Taken by Industry Stakeholders}

Based on the review of reports and articles on the issue, it is possible to sketch the special political and economic relationship between two countries and also the role of Turkish foreign investment and companies in building the modern Turkmen textile industry, which is directly related to cotton production. As Turkish investment in the sector is for export, the outputs are expected to be sold in the global market within the supply chains of global brands. Therefore, the U.S. ban-and the various international campaigns against the country that resulted in corporate decisions to stop sourcing Turkmen cotton - have dealt a blow to the political and economic relationship. Alongside these developments has been a severe financial crisis in Turkmenistan resulting from the fall in oil and gas prices and the costs of the ruling elite's various white elephant projects. The crisis has also negatively affected Turkish firms who have invested locally, with many finding delayed or canceled payments from the Turkmen authorities. In this section, the approaches taken by global corporations and Turkish suppliers with respect to the Turkmen cotton industry will be elaborated.

\footnotetext{
6 https://medyascope.tv/2018/03/01/unlu-mimar-ve-muteahhit-erol-tabancanin-turkmenistanda-zirveyecikisi-ve-oradan-inisinin-oykusu/

https://www.dunya.com/kose-yazisi/turkmenistanda-turk-sirketine...?utm_source=partners\&utm medium=gazeteoku.com\&utm_campaign=feed

7 http://www.sanayicidergisi.com.tr/sevmedigimiz-hicbir-yere-gitmiyoruz-makale,438.html
} 


\section{Approaches of Global Garment Brands}

Some global garment brands have openly declared their intention to exclude Turkmen cotton from their supply chains. Brands disclose their commitment to not using cotton sourced in Turkmenistan and Uzbekistan. Many brands sourcing from Turkey contacted during the present research have adopted similar policies. Based on our interviews with global apparel brands, for instance,

* Columbia Sportswear Company ${ }^{8}$ (CSC) informed all its suppliers not to use cotton or textiles sourced from Uzbekistan and Turkmenistan because of state-orchestrated forced labour in the sector. CSC has noted, however, that global cotton markets are highly complex and difficulty to trace with certainty.

* Since December 2015, H\&M has banned Turkmen cotton from its supply chain. All its suppliers pledged not to purchase cotton from Turkmenistan.

* Primark banned cotton from Uzbekistan in 2015 due to the risk of forced labour in cotton farming and extended the ban to Turkmenistan in 2016.

* IKEA firstly stated that it has just one supplier in Turkmenistan and it was audited frequently. IKEA intends to remain in the country to contribute to positive change. However, products from the firm's Turkmen supplier cannot be imported to the U.S. or the UK. In 2017, IKEA also stopped sourcing from Turkmenistan.

* El Corte Ingles does not use Turkmen cotton, and the company's Cotton Strategy commits to sourcing traceable, organic, recycled cotton until 2025.

However, while Corporate Social Responsibility departments provide similar answers, when these questions were posed to the buying departments of certain brands, the research found out that some have no information on the issue, indicating a clear lack of coordination between different departments of corporations which might complicate control over the cotton supply.

Practically speaking, most brands are dealing with issues higher up in the supply chain, they can not track the lower tiers of the supply chain including the source of cotton. While some big brands have more stringent checks that their Bangladeshi and Indian suppliers are not using Uzbek cotton, it is doubtful that the same applies to Turkey not using Turkmen cotton.

Many brands cooperate with the Cotton Campaign, a global coalition of human and labour rights organizations and investors/business groups dedicated to eradicating child and forced labour in cotton production. Its goals are to end the state systems of forced labour in the Uzbek and Turkmen cotton sectors, and many brands are members of the Better Cotton Initiative. Many brands also cooperate with organizations such as the Responsible Sourcing Network, the International Labour Rights Forum and Anti-Slavery International. However, while the better local cotton initiatives in Turkey aim to trace the cotton production in Turkey, they are unable to focus closely on Turkmen cotton. Therefore, even if being a member of such initiatives is important, it does not necessarily signify insurance against the use of Turkmen cotton.

Ultimately, the effective traceability of cotton is a significant challenge. Inditex ${ }^{9}$

8 https://www.mountainhardwear.com/on/demandware.static/-/Sites-MountainHardwear_US-Library/ default/dw3649de41/Media/Uzbekistan\%20and\%20Turkmenistan\%20Cotton\%20Statement\%202018.pdf

9 Inditex Group owns many brands such as Zara, Massimo Dutti, Bershka and Oysho 
explains its policies as follows:

"Even though Inditex does not source cotton directly, cotton is a very relevant issue on the Group's sustainability agenda as raw materials, and specifically cotton, are key elements in the manufacturing of the finished products that Inditex sells. Therefore, the company has implemented different initiatives to promote cotton traceability and sustainability in the cotton sector in different countries. In this sense, in 2017 Inditex signed a public-private agreement with the International Labour Organisation (ILO) to strengthen labour rights and principles in cotton production and to contribute to the sustainability of the supply chain down to the last link. Through this collaboration, Inditex has improved its knowledge of the supervision and control processes of the raw materials needed to produce garments, from both the traceability perspective and improvement of working conditions. Besides, Inditex cooperates with other initiatives to promote cotton sustainability, for example, the Better Cotton Initiative, Textile Exchange and Organic Cotton Accelerator."

Many brands also support lobbying activities against the Turkmen authorities. For instance, in June 2016 many global brands signed a letter sent by the Cotton Campaign commending the U.S. Department of State's decision to downgrade the governments of Uzbekistan and Turkmenistan to Tier 3 status in the 2016 Trafficking in Persons Report (TIP). ${ }^{10}$

In terms of mapping the sources of cotton, global garment brands struggle to retain continuous visibility down to the lowest levels of the supply chain. This is a challenge for brands because modern slavery and forced labour are more likely to occur in the lower tiers of the supply chain - precisely where the leverage of brands to address such issues is weakest, given the indirect nature of the relationship between brands and these suppliers. It is easier where there is vertical integration between garment factories, textile mills etc. However, much cotton is bought and sold as a commodity, and that is where visibility is lost. Additionally, the Turkish garment industry is based on a multi-tier system which makes even more difficult to reach out to Tier 2 and Tier 3 suppliers where there is a high risk of informal and child labour issues.

Many brands thus adopt a generic ban on Uzbek and Turkmen cotton. The main method is asking suppliers to declare the country of origin of their cotton. As traceability of cotton is a difficult issue, collaboration with suppliers is a requirement to employ these policies in the field. Without any effective support from suppliers, it is not possible for brands to ensure that their commitments have any impact. In addition to the individual efforts of brands, multi-stakeholder initiatives ${ }^{11}$ (MSIs) play a significant role in fostering the tracing/sourcing transparency agenda which brings together global brands, local suppliers, trade unions and NGOs. Many brands are members of MSIs and other similar associations to conduct projects with other stakeholders to promote humane working conditions.

In the Turkish case, both MSIs and brands have additional agendas, which will take priority. The legal employment of Syrian refugees, unionization, social dialogue, fair/ living wages, and gender equality are the main topics where brands, suppliers and trade

10 http://www.cottoncampaign.org/uploads/3/9/4/7/39474145/cc-ussecstate_jtip_turkmenistan-uzbekistan_30 june2016.pdf

11 Multi-Stakeholder Initiatives (MSI) are alliances of global corporations, trade unions and NGOs to tackle labour and environmental-related issues in the global supply chain. 
unions negotiate and work together. It is clear that Turkmen cotton is not on this agenda. Without putting Turkmen cotton on the agenda, it is difficult to take further effective steps. Collaboration in this area would not only advance tracing of cotton in the supply chain but would also open opportunities to lobby Turkish authorities to use their leverage over Turkmenistan to encourage its government to take positive steps to eliminate all forced labour.

MSIs such as the Ethical Trading Initiative (ETI) are also participating in the Cotton Campaign, and the issue of cotton from Uzbekistan and Turkmenistan has been raised with corporate members on numerous occasions. This, however, is at the global level rather than at the level of the work in Turkey. For instance, Turkmen cotton is not on the agenda of ETI's Turkey Program. However, there have been discussions about tackling issues deeper in the supply chain. These debates could attract the attention of stakeholders in Turkmen cotton as well. We have already seen this in the case of another MSI, the Fair Wear Foundation, which is very much aware of the Turkmen cotton issue, but has been unable so far to bring it within their verification system. MSIs can also help or guide their members during due diligence processes to identify if there is a risk that their cotton may be coming from Turkmen or Uzbek sources. This should also be identified in their modern slavery statement.

\section{Approaches taken by Turkish Industry Actors}

The research asked Turkish suppliers specifically about the approach they are taking on the issue of Turkmen cotton. We received answers from several business associations that represent Turkish garment and textile companies and a number of firms that supply global brands. Their answers had some points in common:

First, Turkish textile and garment businesses are aware of the U.S. ban and the international campaigns against Turkmen and Uzbek cotton. They are informed by their customers, and they also follow the debates in the global arena closely. They are also aware of Turkey's significance for the Turkmen cotton industry and the large impact of Turkish textile investments in the country. Therefore, they all underline that companies sourcing for global brands do not purchase Turkmen cotton. They are audited continuously by global brands, and they value highly the policies and expectations of their customers.

Second, the percentage of Turkmen cotton and Turkmen textiles in the Turkish production system is very low. For this reason, according to Turkish suppliers, the Turkmen cotton issue and international campaigns around this theme are marginal to the Turkish textile sector. Turkey is not dependent on Turkmen cotton and can easily find alternative sources. The U.S. ban on Turkmen cotton has therefore not had an impact on the daily business of Turkish textile companies. This also might mean that any international pressure or project targeting Turkish suppliers' consumption of Turkmen cotton might encourage Turkish suppliers to cut off their relations with Turkmenistan altogether.

Third, Turkish suppliers and business associations are swamped by the many projects they undertake with global brands, MSIs, the EU and a number of UN agencies. All these projects - which cover diverse issues, such as the legal employment of Syrian refugees, unionization, social dialogue, purchasing practices, living wages and gender equalitytake up a lot of time and energy and local actors seem to be tiring of all these requests, 
obligations and debates. Therefore, they are not pleased that a new topic has been placed on the agenda to satisfy the seemingly unending demands of global corporations.

Fourth, given the special political relationship between Turkey and Turkmenistanand the direct investments there by many well-known and influential Turkish companies that also have close relationships with the Turkish authorities-firms and business associations are reluctant to take an active stance against Turkmen cottonnor are they willing to openly call on the industry not to invest in or trade with Turkmenistan.

Fifth, some Tier $1^{12}$ suppliers are aware of these campaigns and the demands of global corporations but they do not perceive it as one of their duties. For instance, we received answers from Tier 1 companies indicating that this is not an issue for them and that it is companies producing the cloth in the lower tiers that should take action and audit where they source from. However, global brands essentially expect Tier 1 companies to collaborate and to help trace lower tiers.

I could also able to talk with senior staffs at some of the Turkish textile companies in Turkmenistan, and their observations on the issue are examined. The information shared here is limited as we have had to anonymize these interviewees. The common observations are as follows.

First, senior staffs stated that they do not directly observe forced mobilization and transportation of people to the farms. They did comment, however, that during the harvest in rural areas and small towns everybody leaves their homes, turning these communities temporarily into ghost towns. All family members - adults and children - work together during the harvest. The main reason is that people lease a small portion of land from the state and are required to meet their allotted quota for cotton, meaning the entire family must work to ensure the harvest is successful. According to the company staff, children and students are essentially working on the families' own plot of land. Even these comments are categorically rejected by the Alternative Turkmenistan News.

They also mention that following independence, many European textile companies invested in Turkmenistan and brought brand new machines to open factories. However, the Turkmen investment environment and business culture are different, and almost all European companies left Turkmenistan in short order. Most left the facilities and equipment, most probably with compensation from the state. Turkish textile investors have been able to work in this environment and were able to move into the discarded facilities and return to operations following a little maintenance and repair work. Turkish companies also built brand new facilities.

The senior staff also mentioned that some Turkish companies have been in trouble over payment and that some high-level managers had been imprisoned. They noted, however, that as long as the company meets its contract obligations, the Turkmen authorities do not delay payment or create any problems. If contract violations are found, however, then problems might occur given the country operates essentially without the rule of law. Additionally, they stated that Turkish companies had a very close relationship with President Niyazov, who died in 2006, because, according to them, he was a Moscow-

12 Tier 1 companies are the local suppliers which directly signs agreements with global brands, and distribute the order to lower levels of the supply chain. 
educated bureaucrat and knew the balance of power and supported business. However, the new president does not have that qualification, and he has not been able to manage a sustainable relationship with foreign companies successfully. For instance, despite the long and intense relationship between the countries, Turkmenistan does not grant visafree travel to Turkish citizens.

When these officials are asked if Turkmen cotton and textile products could be exported to Turkey and labelled as "Made in Turkey" after the ban on Turkmen cotton, they claimed that it is difficult to engage in such deceptive practices for an extended period. It is certainly not impossible - in the first years after independence it was the norm before Turkmen authorities insisted that the "Made in Turkmenistan" apply. However, even if there were attempts to skirt the ban in this way, it is unlikely much product would make it to Western markets.

\section{Conclusion}

It is clear that the Turkmen cotton issue is not on the agenda of either global corporations working in Turkey or Turkish suppliers. This reality is reflected in their corporate approaches, the answers they give to researchers and the various existing position papers as well. In the case of issues like the legal employment of Syrian refugees or social dialogue, brands and Turkish business associations are happy to provide much documentation concerning projects, concrete targets, achievements and best practices. However, in the case of Turkmen cotton, industry stakeholders are reluctant to share information, and many of the steps that have been taken on the issue have come under the umbrella of global campaigns - such as lobbying the U.S. government - and not local Turkish initiatives.

The efficiency of sharing documents with suppliers to ensure non-use of Turkmen cotton is debatable, especially because these policies may not even reach the buying departments within the same company. To trace cotton, brands should collaborate with their suppliers, and such collaboration can only come from mutual understanding built up over time through training sessions and meetings.

Tracing cotton is a difficult task and there is a plethora of well-established mechanisms for hiding its origins. The prevalence of bribery and double bookkeeping in addition to the political relationship between Turkey and Turkmenistan represent major obstacles to a transparent regime of tracing cotton origins. Also as Turkish investors produce textile producs for the global market, there has not been a significant change in their production level despite the international boycott. How they distribute these products should be clarified.

Two different strategies toward Turkish textile production can be implemented to promote humane working conditions and stop forced labour in Turkmenistan. In both strategies, global brands, Turkish suppliers and other stakeholders should decide to work together by including Turkmen cotton into their joint agenda of negotiation and collaboration.

The first strategy is a moratorium on all cotton trade from Turkmenistan. This policy might risk future direct investment in Turkmenistan and could force some businesses to conceal their operations. 
The second strategy should be to deploy the leverage of Turkish companies and government over Turkmen authorities to meet their international commitments and obey the rules. There are three reasons supporting this second strategy. First, Turkey retains an intense and close relationship with the Turkmen authorities. Second, Turkish direct investment more or less established the modern Turkmen textile industry, and any boycott policy would harm the interests of Turkish companies as well. Business associations would prefer not to target influential members. Third, Turkey is Turkmenistan's only trading partner which can act as a bridge to the Western market for Turkmen products. Therefore, the active involvement of Turkish business associations and lobbying on Turkish government could constitute definitive leverage to convince Turkmen authorities to accept internationally recognized norms and phase out forced/compulsory labour in the country.

Grant Support: The author received no financial support for this work.

\section{References}

\section{Books and Articles}

Bashimov, G. (2015). Turkmenistan's comparative advantage in international trade: A case study of textile industry. Adnan Menderes University, Journal of Institute of Social Sciences, 2(2), 12-21.

Bashimov, G. (2016). Competitiveness analysis of Turkmenistan's cotton sector. Journal of Agricultural Faculty of Uludag University, 30(1), 1-16.

Bashimov, G., \& Çiçek, R. (2016). Determination of central Asia's comparative advantage in cotton trade. Int. Journal of Management Economics and Business, 12(28).

Bashimov, G., \& Çiçek, R. (2015). Market structure in Turkmenistan and evaluation of Turkmenistan market in terms of the marketing mix. Karadeniz Sosyal Bilimler Dergisi, 7(12), 255-265.

Bohr, A. (2016). Turkmenistan: Power, politics and petro-authoritarianism. London: Chatham House.

Dinç, A., Yayar, R., \& Erol, Y. (2010). Turkmenistan in the 21 st century, a general approach from economic, social, administrative, political and cultural aspects. Gaziosmanpaşa University, Faculty of Economics and Administrative Sciences Publications, No 9. Tokat. (In Turkish).

Güneş, H. (2004). Development Models in Central Asia in Post-Soviet Period: A Comparative Analysis of the Structural Transformation" in Development and Globalisation Ed by Dedeoğlu, Saniye and Subaşat, Turan. İstanbul: Bağlam Yayınları. (In Turkish).

Güneş, H. (2012). "Turkey-Central Asia Relationsin" The Analysis of Turkish Foreign Policy in the 21st Century Ed by Sönmezoğlu, Faruk, Özgür, Nurcan and Terzi, Özlem. İstanbul: DER Yayınları. (In Turkish).

Jumayev, I. (2012). "Foreign Trade of Turkmenistan: Trends, Problems and Prospects" University of Central Asia, Institute of Public Policy and Administration Working Paper, No 11.

Kandiyoki, D. (2005). The Cotton Sector in Central Asia Economic Policy and Development Challenges. Proceedings of a Conference held at SOAS University of London, 3-4 November.

Kovusava, Ş. (2018). Republic of Turkmenistan and macroeconomic structure before and after independence. Göller Bölgesi Aylık Hakemli Ekonomi ve Kültür Dergisi, 5(58), 43-48. (In Turkish).

Merrill, M. (2015). Turkmenistan: Fixing decades of damage. International Higher Education, Center for International Higher Education, Campion Hall, Boston College, No 56, USA.

Mogilevskii, R. (2012). Trends and patterns in foreign trade of central Asian countries. University of Central Asia, Institute of Public Policy and Administration Working Paper. No 1.

Pastor, G., \& Rooden, R. van. (2000). Turkmenistan-The burden of current agricultural policies. IMF Working Paper, No 98.

Payzyllayev, B. (2007). The Concept of Foreign Direct Investment and Turkish Foreign Direct Investment in Turkmenistan. Unpublished MA Thesis, Selçuk University, Institute of Social Sciences, Konya.

Peyrouse, S. (2015). Turkmenistan: strategies of power, dilemmas and development. London: Routledge.

Pomfret, R. (2016). Modernizing agriculture in central Asia. Global Journal of Emerging Market Economies, $8(2), 104-125$.

Pomfret, R. (2014). Trade and human development. Central Asia Human Development Series. United Nations Development Programme Regional Bureau for Europe and the Commonwealth of Independent States.

Pomfret, R. (2011). From communism to nationalism by gradual economic reform. School of Economics University of Adelaide, Australia. 
Stronski, P. (2017). Turkmenistan at twenty-five: The high price of authoritarianism. Carniege Endowment for International Peace. https://carnegieendowment.org/2017/01/30/turkmenistan-at-twenty-five-high-priceof-authoritarianism-pub-67839.

Terzioğlu, S. S. (2013). International treaties in the legal system of Turkmenistan. Law \& Justice Review, 4(2), 73-87.

Turan, G., \& Dinç, A. (2015). The history of Turkmen economy from Soviet Slavery to energy empire. Ankara: Gazi Kitabevi. (In Turkish).

Vaughan, A. M. (2005). Factors Affecting Plant Density and Cotton Yields in Turkmenistan, Unpublished PhD Thesis. University of Western Sydney, Australia.

\section{Media}

Alternative Turkmenistan News. 14/11/2016. Forced Labor, or Why Turkmen Markets Are Packed with BrandName Textiles, https://habartm.org/archives/6051

Alternative Turkmenistan News. 01/09/2018. Turkmenistan Forces State Workers into New Cotton- picking Campaign. https://habartm.org/archives/9434

Alternative Turkmenistan News. 02/10/2017. IKEA Bans Turkmen Cotton from its Products. https://habartm. org/archives/7820

Alternative Turkmenistan News. 26/01/2017 “Teenagers are less likely to be bought." Present-day slavery in Turkmenistan in the cotton sector, https://habartm.org/archives/6347

Alternative Turkmenistan News. 01/02/2018 “Turkmenistan: 2017 Findings of Forced Labor Monitoring during Cotton Harvesting" https://habartm.org/archives/8496

Alternative Turkmenistan News. 27/08/2017, Turkmenistan kicks off mobilization of civil servants for cotton season, https://habartm.org/archives/7611

Çağlayan, Z. (2014). Ekonomi Bakanı Zafer Çağlayan Atavatan Türkmenistan İçin Yazdı. http:/www.turkiyeturkmenistan.com/ekonomi-bakani-zafer-caglayan-atavatan-turkmenistan-icin-yazdi/

Foreign Economic Relations Board. (2015). Türkmenistan Yatırım Forumu İstanbul'da Gerçekleşti, https:// www.deik.org.tr/basin-aciklamalari-turkmenistan-yatirim-forumu-istanbul-da-gerceklesti

Etkihaber 23/09/2009 Türk Şirketinden, Türkmenistan'a Yeni İplik Fabrikası, http://www.etkihaber.com/turksirketinden,-turkmenistana-yeni-iplik-fabrikasi--10862h.htm

Ewart-James, J. 05/02/2018. "Gaspar Matalaev: serving time for reporting on forced labour in Turkmenistan's cotton fields." Independent. https:/www.independent.co.uk/voices/campaigns/voicesindanger/servingtime-for-reporting-on-forced-labour-in-cotton-fields-a8194961.html

euroasia.net 29/05/2018. Turkmenistan: Cotton bans and whitewashes https://www.eurasianet.org/turkmenistancotton-bans-and-whitewashes

H\&M 12/02/2016. Ban on Cotton from Turkmenistan and Syria, https://about.hm.com/en/media/news/ban-oncotton-from-turkmenistan-and-syria.html

Hürriyet 22/10/2003. We invested 1 billion Dollar in Turkmenistan, http://www.hurriyet.com.tr/ekonomi/ tekstilde-turmenistana-1-milyar-dolar-yatirdik-178632 (in Turkish)

IKEA. Statement: Cotton from Turkmenistan. https://www.ikea.com/ms/en_US/pdf/reports-downloads/IKEA_ Statement Cotton from Turkmenistan.pdf

Kapadia, S. $\overline{0} 1 / 06 / 2018$. Apparel brands take a closer look at sourcing after cotton ban. https://www. supplychaindive.com/news/cotton-sourcing-turkmenistan-CBP-forced-labor/524606/

Mathews B. 09/08/2018. Child labour concerns return for Turkmenistan cotton - Apparel Insider. https:// apparelinsider.com/child-labour-concerns-return-for-turkmenistan-cotton/

Munyar, V. 07/09/2014. Sevmediğimiz hiçbir yere gitmiyoruz, http://www.sanayicidergisi.com.tr/sevmedigimizhicbir-yere-gitmiyoruz-makale,438.html (Interview on Turkish invesment in Turkmenistan)

Central Asia Research Centre. 10/09/2018 Türkmenistan 1 milyon tonluk pamuk toplamaya başladı http:// orasam.manas.edu.kg/index.php/tr/turkmenistan/981-t-rkmenistan-1-milyon-tonluk-pamuk-toplamaya-balad

Petrick, M. (2016). Agricultural policies in Central Asia: What governments do, why they do it, and what they should do, IAAE Inter-Conference Symposium "Agricultural Transitions along the Silk Road" Almaty, 5 April 2016

Rickleton, C. 03/11/2014. Forced Labor Still Systematic in Turkmenistan - Report | Eurasianet, https:// eurasianet.org/forced-labor-still-systematic-in-turkmenistan-report

TimeTurk. 25/05/2018. ABD, Türkmenistan'dan pamuklu ürünlerin ithalatını yasakladı! https://www.timeturk. com/abd-turkmenistan-dan-pamuklu-urunlerin-ithalatini-yasakladi/haber-903897

Türkyurdu Haber. 23/10/2017. Türkmenistan’da Pamuk Üretimi Yüzleri Güldürdü, https:/www.turkyurduhaber. org/haber/28812/turkmenistanda-pamuk-uretimi-yuzleri-guldurdu.html

Türkiye \& Türkmenistan (Unknown), Why Turkmenistan? http://www.turkiye-turkmenistan.com/is-birligifirsatlari/ (In Turkish) accessed 14/09/2018

Türkiye \& Türkmenistan (Unknown) Tekstil. http://www.turkiye-turkmenistan.com/is-birligi-firsatlari/ turkmenistan-da-tekstil/ accessed 14/09/2018 
Türkiye \& Türkmenistan (Unknown) Türk Firması Engin Gruba Yeni Projeler Verildi http://www.turkiyeturkmenistan.com/turk-firmasina-onemli-gorev-3/ Accessed 14/09/2018

Türkiye \& Türkmenistan (Unknown) Türk Firmasından Muhteşem Aç1lış http://www.turkiye-turkmenistan. com/turk-firmasindan-muhtesem-acilis/ Accessed 14/09/2018

Türkiye \& Türkmenistan (Unknown) Türk Firmasından Önemli Çalışma, http://www.turkiye-turkmenistan. com/turk-firmasindan-onemli-calisma/ Accessed 14/09/2018

Türkiye \& Türkmenistan (Unknown) Türkmenistan Pamuk Üretiminde Rekora Koşuyor http://www.turkiyeturkmenistan.com/turkmenistan-pamuk-uretiminde-rekora-kosuyor/ Accessed 14/09/2018

Türkiye \& Türkmenistan (Unknown) Türkmenistan Tekstil Sanayi'de 1 Milyar Dolarlık Yabancı Yatırım Bekliyor http://www.turkiye-turkmenistan.com/turkmenistan-tekstil-sanayide-1-milyar-dolarlik-yabanciyatirim-bekliyor/ Accessed 14/09/2018

Türkiye \& Türkmenistan (Unknown) Türkmenistan Tekstil Sergisine Türk Firmaları Damgasını Vurdu http:// www.turkiye-turkmenistan.com/turkmenistan-tekstil-sergisine-turk-firmalari-damgasini-vurdu/ Accessed 14/09/2018

Türkiye \& Türkmenistan (Unknown) Türkmenistan'da Tekstil Sektörü, http://www.turkiye-turkmenistan.com/ turkmenistanda-tekstil-sektoru/ Accessed 14/09/2018

Wikipedia, Economy of Turkmenistan. https://en.wikipedia.org/wiki/Economy_of_Turkmenistan Accessed 14/09/2018.

\section{Reports and Blogposts}

Amnesty International (2018) Turkmenistan 2017/2018 Annual Report. https://www.amnesty.org/en/countries/ europe-and-central-asia/turkmenistan/report-turkmenistan/

Ateş, Ş. (2012). Turkmenistan Country Report. KASIAD (In Turkish- prepared for the Business Association in Kocaeli Turkey)

CIA, 2018, Turkmenistan Country Report, https://www.cia.gov/library/publications/the-world-factbook/geos/ tx.html

Columbia Sports Wear. 2018. Uzbek and Turkmen Cotton - Position Statement, https:/www.mountainhardwear. com/on/demandware.static/-/Sites-MountainHardwear_US-Library/default/dw3649de41/Media/ Uzbekistan\%20and\%20Turkmenistan\%20Cotton\%20Statement\%202018.pdf

Çalık Cotton. 2014. Kurum Profili 2014, http://calikcotton.com/pdf/Calik-Cotton-Kurum-Profili-2014.pdf

Ergon. 2018. Modern slavery reporting: Is there evidence of progress? October 2018. http://ergonassociates.net/ publication/modern-slavery-reporting-evidence-progress/

European Commission, Directorate General for Trade, 2018. European Union, Trade in goods with Turkmenistan https://webgate.ec.europa.eu/isdb_results/factsheets/country/details_turkmenistan_en.pdf

Exportiamo, 2016. Turkmenistan, the Republic of gas and cotton, http://www.exportiamo.it/areetematiche/12849/turkmenistan-the-republic-of-gas-and-cotton/

Konca, Koray Ali. 2011. Turkmenistan Country Report. Dış Ticaret Müsteşarlığı İHRACATI GELİSTTIRME ETÜD MERKEZİ (In Turkish-Centre for Promoting Exportation)

Ministry of Foreign Affairs, Republic of Turkey.2016. Economy of Turkmenistan http://www.mfa.gov.tr/ turkmenistan-ekonomisi.tr.mfa (In Turkish)

MÜSİAD. 1996. Cotton Union, MÜSİAD Research Report 19 (In Turkish Independent Industrialists' and Businessmen's Association MÜSİAD)

Samsun TSO. 2016. Turkmenistan Country Report. http://www.samsuntso.org.tr/upload/Dosyalar/Yayinlar/ UlkeRaporlari/Turkmenistan-2016.pdf (In Turkish- Samsun/Turkey Chamber of Industry and Trade)

Sirtıoğlu, İ. (2018). Turkey Cotton and Products Annual Report 2018. Global Agricultural Information Network, TR8009, USDA Foreign Agricultural Service

Skrivankova, K. (2018). Brands should boycott Turkmenistan cotton over use of forced and child labour, Ethical Trading Initiative Blog. https:/www.ethicaltrade.org/blog/brands-should-boycott-turkmenistan-cottonover-use-forced-and-child-labour

Skrivankova, K. (2015). Why you could be wearing cotton picked by forced labor, https://edition.cnn. com/2015/10/02/opinions/uzbekistan-turkmenistan-cotton/index.html

DEIK Turkish-Turkmen Business Council. 2012. Turkey-Turkmenistan Trade and Business Relations. (In Turkish)

United Nations Human Rights Committee. 2012. Human Rights Committee Notes Turkmenistan's 'New Willingness' to Improve Human Rights Record, but Says Gap Remains between Legal Framework, Implementation. 104th Session, 2871st \& 2872nd Meetings

\section{Interviews}

Martin Buttle, Ethical Trading Initiative, 22/10/2018

Andriette Nomensson, Fair Wear Foundation, 23/10/2018

Dr Nurlan Muminov, Istanbul University, 20/10/2018

Şükran Bayçura, Better Cotton Turkey (İyi Pamuk Derneği), 01/11 and 12/11/2018 
Hale Gülbaz, ITKIB Istanbul Textile Exporters Association, 05/11/2018

Muharrem Kayhan TTSIS, Turkish Textile Employers Union, President, 19/10/2018

Ülkem Yaman, TGSD, Turkish Clothing Manufacturers Associations, General Secretary, 20/10/2018

Engin Çelik, Deriteks Trade Union 06/10/2018

Ergun İşeri, DISK Tekstil 06/10/2018

Manager X, Y, Z, T: Managers of Turkish textile plants in Turkmenistan 05 and 07/11/2018

Supplier X, Y, Z Turkish suppliers sourcing for global brands 05/10/2018

Serdar Akar, Turkish Embassy, Office of Commercial Couselor, Ashgabat, Turkmenistan, 22/10/2018

Primark, CSR, 08/11/2018

Inditex, CSR, 31/10/2018

H\&M, CSR, 12/11/2018

El Corte Ingles, CSR, 20/10/2018

Brand X and Y, Buying Departments, 21/10/2018 
